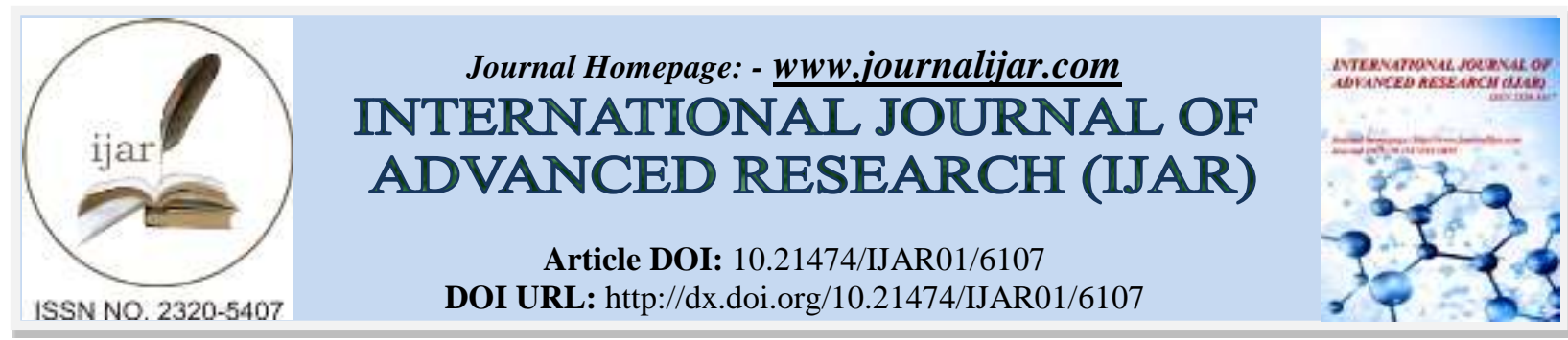

RESEARCH ARTICLE

\title{
INFLUENCE OF SIZE, GROWTH AND PROFITABILITY OF COMPANY TO EARNINGS RESPONSE COEFFICIENT.
}

Suwarno, Tumirin and Zamzami.

Departement of Accounting, FEB, University Of Muhammadiyah Gresik.

\section{Manuscript Info}

Manuscript History

Received: 19 October 2017

Final Accepted: 20 November 2017

Published: December 2017

Keywords:-

Size, Growth, Profitability, Earnings

Response Coefficient.

\begin{abstract}
Earnings contain the information reflected in the stok price and investors will react over the information published by the entity. The response of the market over the financial statement information can be measured by earning response coefficient. Some of the factors that affect the earning's response are the company's size , the company's growth and profitability. This research aims to conduct empirical testing against the influence of the company's size, the company's growth and profitability against earnings response coefficient on manufacturing companies listed on the Indonesia stock exchange (IDX) the period of 2013-2015. The sampling techniques used by using purposive sampling. Testing is done using multiple linear regression. The regression results show that influential company profitability significantly to earnings response coefficient, but the size and growth of the company has not shown significant effects earnings response coefficient .
\end{abstract}

Copy Right, IJAR, 2017,. All rights reserved.

\section{Introduction:-}

The financial statements are a reflection of the company's financial condition because the financial statements contain the profit information needed by stakeholders. One indicator that an accounting information is relevant is the reaction of investors at the time of the announcement of financial statements of stock price movements (Naimah and Utama, 2006). Because profits are used as a basis for measuring company performance over a certain period, and can be used to predict future cash flows. The use of earnings information, can reduce the uncertainty of financial performance of the company in the future, so the quality of decision making will increase.

The accounting profit is related to the valuation of the company presented with the stock price. Vahini and Putra (2015) conduct research event study, market response to the issuance of financial statements. Research is done by looking at stock price movements several days before and after the issuance of financial statements. The results of this study indicate different stock price fluctuations between days around the issuance of financial statements with other days before the period. These fluctuations represent the market response to stock prices as the basis for understanding the Earning Response Coefecient (ERC). ERC is a variation of the relationship between stock return and profit.

Profit will affect stock returns for investors, on the other hand will affect the value of expected return, which ultimately affects the value of ERC. The strong market reaction to earnings information as reflected in the high

Address:- Departement of Accounting, FEB, University Of Muhammadiyah Gresik. 
earnings response coefficient or ERC, indicates reported quality earnings (Anjelica, Keshia, Prasetyawan, \& Fani A, 2014).

If the quality of profit is better in the future, then the predicted value of ERC will be higher. ERC can show the quality of earnings depending on the abnormal return of stocks seen from the ups and downs of stock prices and market prices based on the profits obtained by the company. Profit quality, stock price will be high because responded very well by the market (Sandi \& Umam K., 2013).

ERC is a reaction to the profit announced (Published) by the company. This reaction reflects the quality of the firm's reported earnings. And high or low ERC determined the responsive power that is reflected from the information (good / bad news) contained in the profit. Companies that report high profits are good news for investors who invest their capital because they will get dividends on each share ownership they have. Likewise with creditors, creditors will feel confident of receiving interest on the return of principal loan that has been given to the company. (Pradipta, Hayu, \& Purwaningsih, 2015). ERC is influenced by several factors including company size, company growth and profitability. (Diantimala \& Yossi, 2008) states that companies with large assets indicate that the company has reached the maturity stage where in this stage the company has a good prospect in the long term, predicted more stable and able to generate profit than small companies. Arfan and Antasari (2008) suggest that an organizational measure is more easily understood by looking at the number of workers in an organization, while sales volume, financial or asset circumstances and geographic spread can be an indicator of the size of the organization.

Companies with larger sizes generally tend to be the center of attention compared to smaller sizes, because in addition to involving larger stakeholders as well as the impact of the company is very large and large. Therefore, firms with larger sizes have the initiative to disclose more information when compared to smaller companies to gain legitimacy from stakeholders, because after all the survival of the company depends on the harmonious relationship with stakeholders (Arfan, Antarsari, \& Ira, 2008).

Large companies there is a lot of non-accounting information throughout the year. Such information is used by investors as a tool to interpret financial statements better, so it can be used as a tool to predict cash flow and reduce uncertainty (Kusuma, Indra, Nugroho, \& SetiyoJ., 2010). At the time of earnings announcement, earnings information will be responded positively by investor. The greater the chance of growth of the company, the higher the chance of the company to get or increase the profit obtained by the company in the future, so that will increase the stock price and market response as well.

States that profitability describes the ability of a company to earn profits in a certain period (Sri, 2014). Profitability can explain that the company's ability to generate profits is dependent on the size of the sale, the investment of assets (investment) and the absorption of equity (equity). In addition, the amount of profitability can be used to assess the company's performance results, because the higher the level of profitability then the better the company's performance. Earnings response coefficients in companies that have high profitability found greater than companies with low profitability (Arfan, Antarsari, \& Ira, 2008). Profitable companies are able to complete the current operations, which are indicated by profit. Profit reflects the results of the use of company resources.

\section{Theory And Development Of Hypotheses:- Efficient Market Theory:-}

Fama classifies the efficient market into three forms of weakly efficient markets, efficient half strong markets, and highly efficient efficient markets (Fama \& Eugne F., 1970). An efficient market is how the market reacts to information to reach a new equilibrium price. If the market reacts quickly and accurately to achieve a new equilibrium price that fully reflects the available information, then such conditions are called efficient markets. Efficient a market can be tested by looking at unusual returns or abnormal returns that occur (Padan \& Peni D., 2006). The market is said to be efficient if the stock price can reflect all the information already available. Efficient market implication is the stock price will react to the announcement of financial statements.

\section{Signaling Theory:-}

Signaling theory is one of the capital structure theories developed to take into account the fact that insider companies generally have better and quicker information relating to current conditions and prospects compared to outside investors. This theory is based on the problem of asymmetric information between well-informed managers and poorly-informed outside investors, as managers do not convey full information on matters affecting company 
value, so there is a tendency to give low ratings to companies of good quality and quality low (pooling equilibrium). So generally the market will respond as a signal to a particular event that can affect the value of the company (Paramita, Daniar, Hidayanti, \& Ery, 2013).

\section{Earnings Response Coefficient (ERC):-}

The earnings response coefficient is an abnormal size measure of market return in response to unexpected earnings (EU) information on stocks. ERC is also called the effect of unexpected earnings shock on Cumulative Abnormal Return, which is shown through slope coefficient in regression of abnormal return of shares with EU (Murwaningsari \& Etty, 2008).

Earnings response coefficient is a market reaction to information published earnings by the company that can be observed from the movement of stock prices around the date of publication of financial statements (Diantimala $\&$ Yossi, 2008). ERC can be searched from the regression result between the proxy of stock price and accounting profit, proxy of stock price using CAR and accounting profit proxy with EU. The value of ERC will be higher if the company's earnings are more persistent in the future and have a good profit quality.

\section{Company Size:-}

The size of the firm is the scale of the firm seen from the total assets of the company at the end of the year. The bigger the company, the more involved or interested, and the center of attention. Larger companies are more likely to pay attention to better performance, as they tend to be subjects to more rigorous public scrutiny, and thus need to respond more openly to stakeholder demand. So larger companies are expected to provide more information disclosure when compared to companies whose size (size) is smaller. In addition, large companies are available for a lot of non-accounting information throughout the year, such as the percentage of stock quotes, auditor reputation, and industry types. Such information is used by investors as a tool to interpret financial statements better, so it can be used as a tool to predict cash flow and reduce uncertainty. At the time of earnings announcement, profit information will be responded positively by investors (Kusuma, Indra, Nugroho, \& SetiyoJ., 2010).

\section{Company Growth:-}

High-growth firms with large opportunities make it possible to pay low dividends because they have a profitable opportunity to fund their investments internally, so companies are not tempted to pay the larger dividend (Arfan, Antarsari, \& Ira, 2008). Growth of the company can affect earnings response coefficient. This is in accordance with previous findings that indicate that firm growth has a positive effect on earnings response coefficients (Collins \& Kothari, 1989). High growth companies will be able to complete their projects. Therefore, the increase in profits will be responded positively by investors.

\section{Company Profitability:-}

is the company's ability to earn a profit (Sri, 2014). This capability stems from the economic profitability of the loan and its own capital invested in assets and the overall operational efficiency of the company concerned. Profitability of a company shows the comparison between profits with the assets or capital that generate such profits. Profitability can be measured by the amount of operating profit, net income, return on investment or assets, and the rate of return on owner's equity.

\section{Effect of Company Size on ERC:-}

The size of the firm is the scale of the firm seen from the total assets of the company at the end of the year. Companies with larger sizes, have more sales, more capital, and more employees. In addition, large companies are available for a lot of non-accounting information throughout the year, such as the percentage of stock quotes, auditor reputation, and industry types. So that big companies are more the center of investor attention compared to small companies. Larger companies are expected to provide more information disclosure when compared to companies of smaller size) (Kusuma, Indra, Nugroho, \& SetiyoJ., 2010). The result of research of) (Ngadiman, Hartini, \& Yurike, 2011)that profit persitensi have an effect on earnings response coefficient. However, firm size, capital structure and indicator variable have no effect on earnings response coefficient. But the results differ on firm size from research conducted by (Kusuma, Indra, Nugroho, \& SetiyoJ., 2010) that CSR disclosure, size, and profitability affect ERC.

$\mathrm{H}_{1}$ : Company size affects earning response coefficient 


\section{The Influence of Corporate Growth on ERC:-}

Company growth is the company's ability to increase the size (size) of the company. Company growth can be measured in several ways, such as by seeing sales growth, operating profit growth, net profit growth, and own capital growth. The greater the chance of growth of the company, the higher the opportunity to earn or increase the profits obtained by the company in the future, so that will increase the stock price and market response as well (Sandi \& Umam K., 2013). The result of Sandi (2013) research that company size influence to ERC. However, the company's growth variable, capital structure and audit quality have no effect on ERC. $s$

\section{$\mathrm{H}_{2}$ : Growth affects ERC}

\section{The Effect of Profitability of Companies on ERC:-}

According Hermuningsih (2014) profitability of the company is the company's ability to earn a profit. The ability to generate profits derived from the management of liabilities and equity invested in assets. Profitability can be measured by the amount of operating profit, net income, return on investment or assets, and the rate of return on owner's equity. Result of research of (Pamungkas \& Bayu, 2014)that profitability influence to earnings response coefficient, while firm size and leverage have no effect. The result of profitability variable to ERC, different from result of research conducted by (Anjelica, Keshia, Prasetyawan, \& Fani A, 2014) hat profitability, company age, capital structure have no effect on earnings quality. However, firm size and audit quality are influential.

\section{$\mathrm{H}_{3}$ : Return On Asset (ROA) affects ERC}

\section{Research Methods:-}

\section{Research Model:-}

The research model developed in this research is as presented in the following figure:

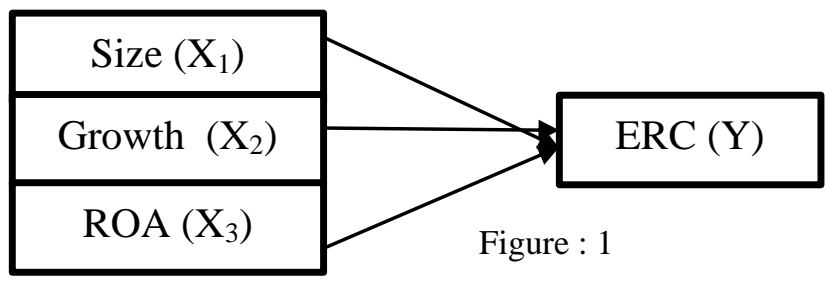

\section{Research Design:-}

The population of this study is a manufacturing company listed on the Indonesia Stock Exchange period 2013-2016. The technique of determining the sample in this study using purposive sampling method. The purposive sampling method is the technique of determining the sample by establishing some considerations and criteria. The sample criteria used are as follows: the company reports the financial statements as of 31 December 2013-2016 consecutively, the financial statements are in rupiah, and the positive after-tax return.

\section{Operational Definition and Variable Measurement:-}

\section{Company Size (X1):-}

Company size is a company asset. This variable is calculated using total assets.

Company Size $=$ Ln (Total Assets).

\section{Company Growth (X2):-}

Company growth is the company's ability to increase company size. This variable is calculated using the Sales Growth Rate.

Sales Growth $=\left(\right.$ Sales $\left(\mathrm{t}_{1}\right)-$ Sales $\left.\mathrm{t}_{0}\right) /\left(\right.$ Sales Period $\left.\mathrm{t}_{0}\right) \times 100 \%$

\section{Profitability (X3):-}

Profitability is the company's ability to earn profits. Variables use Return On Assets (ROA). ROA indicates the level of net profit that the company earned in running its operations.

ROA $=($ Net Profit after Tax $) /($ Total Asset $) \times 100 \%$ 


\section{Earnings Rensponse Coefficient (ERC):-}

$\mathrm{ERC}$ is a measure of abnormal returns as an investor response to unexpected earnings information on stocks. ERC is calculated from the regression result between stock price proxy and accounting profit, stock price is measured by CAR, while Proxy of accounting profit use. In the calculation there are several stages, namely:

\section{The formula calculates daily stock returns:-}

$$
\begin{aligned}
& \quad R_{i t}=\left(P_{i t}-P_{i t-1}\right) / P_{i t-1} \\
& \text { Information : } \\
& \text { Rit = return of stock on day } \mathrm{t} \\
& \text { Pit = closing price of stock on day } \mathrm{t} \\
& \text { Pit-1 } \quad=\text { closing price of stock I on day } \mathrm{t}-1
\end{aligned}
$$

The formula calculates daily market returns:-

$$
\text { Rmt }=(\text { IHSGt }- \text { IHSGt-1) / IHSGt-1 }
$$

Information :

$\begin{array}{ll}\text { Rmt } & =\text { Daily market return } \\ \text { IHSGt } & =\text { composite stock price index on day } \mathrm{t}\end{array}$

IHSGt-1= composite stock price index on day $\mathrm{t}-1$

\section{The formula calculate abnormal return :-}

Arit $=\mathrm{Ri}, \mathrm{t}-\mathrm{Rm}, \mathrm{t}$

Information :

Arit $=$ abnormal return of firm $\mathrm{i}$ in period $\mathrm{t}$

$\mathrm{Ri}, \mathrm{t}=$ return of company stock in period $\mathrm{t}$

$\mathrm{Rm}, \mathrm{t}=$ market return in period $\mathrm{t}$

\section{Calculating Cumulative Abnormal Return:-}

CAR i $(-3,+3)=\Sigma_{-}(-3)^{\wedge}(+3)$

Information :

CAR i $(-3,+3)=$ cumulative abnormal return during the observation period of approximately three days from the date of publication of the financial statements.

Arit $=$ abnormal return of firm $\mathrm{i}$ on day $\mathrm{t}$.

Calculating Unexpected Earnings with a random walk model. EU is the difference in accounting profit expected by the market:-

UEit $=($ AEit - AEit-1) / AEit-1

Information :

UEit $=$ Unexpected Earnings in period t.

AEit $=$ Actual profit (profit after tax) in period $\mathrm{t}$.

AEit-1 = Actual profit (profit after tax) in period $\mathrm{t}-1$.

\section{Calculates the earnings response coefficient:-}

CARit $=\beta 0+\beta 1 \mathrm{UEi}, \mathrm{t}+\mathrm{e}$

Information :

CARIT $=$ Cummulative abnormal return in period $\mathrm{t}$.

$\mathrm{UEi}, \mathrm{t}=$ Unexpected earnings in period $\mathrm{t}$.

$\beta 0=$ Constants

$\beta 1=$ The surprising earnings coefficient, is the ERC

$\mathrm{e}=$ error term

\section{Data analysis method:-}

Data analysis performed consisted of descriptive statistics, normality test, classical assumption, regression and hypothesis test. Descriptive statistics are statistics used to analyze data by describing the data as it is without intending to make conclusions that apply to the public or generalizations. 


\section{Classic assumption:-}

Multicollonierity test was used to test whether the regression model found a correlation between independent and independent variables (Ghozali, 2011). A good regression model should not be correlated between independent variables. Test criteria Multicolonierity with tolerance value $<0.1$ and variance inflation factor (VIF) $>10$.

The autocorrelation test aims to test whether in the linear regression model there is a correlation between the confounding error in period $t$ with the intruder error in period $t-1$ (previous). In general the benchmark of the assessment criteria free of whether or not the test Autocorrelation (Santoso, 2010) are:

The $\mathrm{D}-\mathrm{W}$ number below -2 means there is a positive autocorrelation

The D-W number between -2 to +2 means there is no autocorrelation

The D-W number above +2 means there is autocorrelation

The heterocedasticity test aims whether a regression model of variance inequality varies from one observational residue to another. If the variant from one observation to another observation remains, it is called homokedastisitas and if different is called heterokedastisitas (Ghozali, 2011). Heteroskedastisitas test using Scatterplot test if there is a certain pattern on the scatterplot graph, such as the points that form a regular pattern (wavy, spread and narrow) then the conclusion is there has been heteroscedasticity.

\section{Multiple Linear Regression Analysis:-}

Multiple linear regression analysis model shows correlation between one occurrence with another. Since there are more than two variables, the linear relationship can be expressed in multiple linear regression equations. The equations obtained in the analysis of the data are as follows:

$\mathrm{Y}=\alpha+\beta_{1} \mathrm{X}_{1}+\beta_{2} \mathrm{X}_{2}+\beta_{3} \mathrm{X}_{3}+\varepsilon$,

Where :

$\mathrm{Y}=\mathrm{ERC}$

$\alpha=$ Coefficient of Constants

$\mathrm{X} 1=$ Company Size

$\mathrm{X} 2$ = Company Growth

$\mathrm{X} 3=\mathrm{ROA}$

\section{Hypothesis Test:-}

T-test used to test the influence of independent variables partially to the dependent variable. The tests used a significant level of 0.05 and two sides. Here are the testing stages:

1. Formulating the Statistical Hypothesis.

$\mathrm{H}_{0}, \beta_{1,2,3}=0$, There is no effect of variable size, growth, ROA to ERC.

$\mathrm{H}_{\mathrm{a}}, \beta_{1,2,3} \neq 0$, There is influence of variable size of company, company growth, ROA to ERC

2. Testing criteria

If the value is significant $<0.05$, then $\mathrm{H}_{0}$ is accepted.

If the value is significant $<0.05$, then $\mathrm{H}_{0}$ is rejected.

\section{Results and Discussion:-}

The sample used in this study is a manufacturing company listed on the Indonesia Stock Exchange in 2013-2016. The sampling technique used in this research is purposive sampling technique, with the aim to get representative sample according to the consideration of the researcher. The final result, obtained 18 manufacturing companies used as research samples for 3 periods. The following are descriptive statistics of the research sample.

Table 4.7:- Descriptive statistics

\begin{tabular}{|l|r|r|r|r|}
\hline & \multicolumn{1}{|c|}{ Minimum } & \multicolumn{1}{c|}{ Maximum } & \multicolumn{1}{c|}{ Mean } & \multicolumn{1}{c|}{ Std. Deviation } \\
\hline Size & 25,798 & 32,151 & 29,18217 & 1,728831 \\
\hline Growth &,- 255 &, 476 &, 12311 &, 109096 \\
\hline ROA &, 015 &, 445 &, 14175 &, 108832 \\
\hline ERC &,- 392 &, 518 &, 02780 &, 181402 \\
\hline
\end{tabular}

Based on the results of descriptive statistics in the table above, it can be seen that the ERC variable has an average value of 0.02780 . The size of the company with an average of 29.18217. Furthermore, the growth of companies with 
an average value of 0.12311 . The last independent variable is ROA with an average value of $13.4 \%$, the figure shows the efficiency of the company in managing the assets to get profit.

\section{Classic Assumptions:-}

Normality test aims to test whether the research data has been normally distributed. The kolmogorov-smirnov test showed that the significance value was 0.076 or greater than $5 \%$. In addition, as evidence supporting the normality of data, following the test graph of data normality.

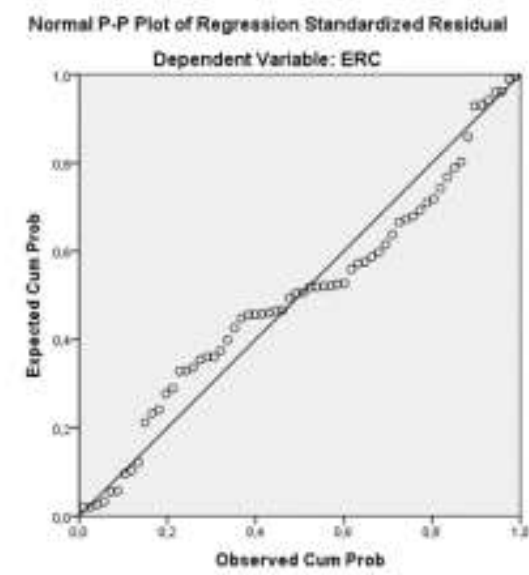

Figure 4.1 above shows the results of normality test data spread around the diagonal line so that it can be concluded that the data used in this test model already meet the assumption of normality. Thus, the data used in this study can be said to be normal and feasible for the process of regression analysis.

Multicollinearity test aims to test the correlation between independent variables. Here are the results of multicollinarization testing in this study:

Table 4.9:- Multicollinearity Test Results

\begin{tabular}{|c|c|c|c|c|c|c|c|c|}
\hline \multirow{2}{*}{\multicolumn{2}{|c|}{ Model }} & \multicolumn{2}{|c|}{$\begin{array}{c}\text { Unstandardized } \\
\text { Coefficients }\end{array}$} & \multirow{2}{*}{$\begin{array}{c}\text { Standardized } \\
\text { Coefficients } \\
\text { Beta }\end{array}$} & \multirow[t]{2}{*}{$\mathrm{t}$} & \multirow[t]{2}{*}{ Sig. } & \multicolumn{2}{|c|}{ Collinearity Statistics } \\
\hline & & $\mathrm{B}$ & Std. Error & & & & Tolerance & VIF \\
\hline \multirow[t]{4}{*}{1} & (Constant) & ,095 & ,383 & & 249 & ,804 & & \\
\hline & Size &,- 001 & ,013 &,- 008 &,- 067 & ,947 & ,948 & 1,055 \\
\hline & Growth & 176 & 206 & , 106 & 850 & ,399 & 981 & 1,019 \\
\hline & ROA &,- 447 & 213 &,- 268 & $-2,103$ &, 040 & ,931 & 1,074 \\
\hline
\end{tabular}

a. Dependent Variable: ERC

Based on the test results that have been done and presented clearly in table 4.9, it can be concluded that the three independent variables do not occur multicollinearity, which is indicated by the tolerance value $>0.10$ and VIF $<10$

The autocorrelation test aims to test whether in the linear regression model there is a correlation between the confounding error in period $\mathrm{t}$ with the intruder error in period $\mathrm{t}-1$ (previous). Autocorrelation arises because of sequential observations over time related to each other (Ghozali, 2011). To detect the occurrence of autocorrelation then tested using Durbin-Watson.

Table 4.10:- Autocorrelation results

\begin{tabular}{|l|r|r|r|r|r|}
\hline Model & R & R Square & Adjusted R Square & $\begin{array}{c}\text { Std. Error of the } \\
\text { Estimate }\end{array}$ & Durbin-Watson \\
\hline 1 &, $303^{\mathrm{a}}$ &, 092 &, 046 &, 177138 & 1,647 \\
\hline \multicolumn{7}{|l|}{ a. Predictors: (Constant), Size, Growth, ROA } \\
\hline
\end{tabular}


Based on the test that has been done with the results shown in table 4:10, it can be concluded that in the regression model that there is no autocorrelation, it is seen from the value of D-W (Durbin - Watson) $=1.647$ or du $<1.647<4$ du.

The heterocedasticity test aims to examine the variant inequality of the residual one observation to another. If the variant from one observation to another observation remains, it is called homokedastisitas and if different is called heterokedastisitas (Ghozali, 2011). In the Scatterplot test, if there is no clear pattern, and spreading dots, then the indication is no heterokedastisity.

Figure 4.2:- Heteroscedasticity Test

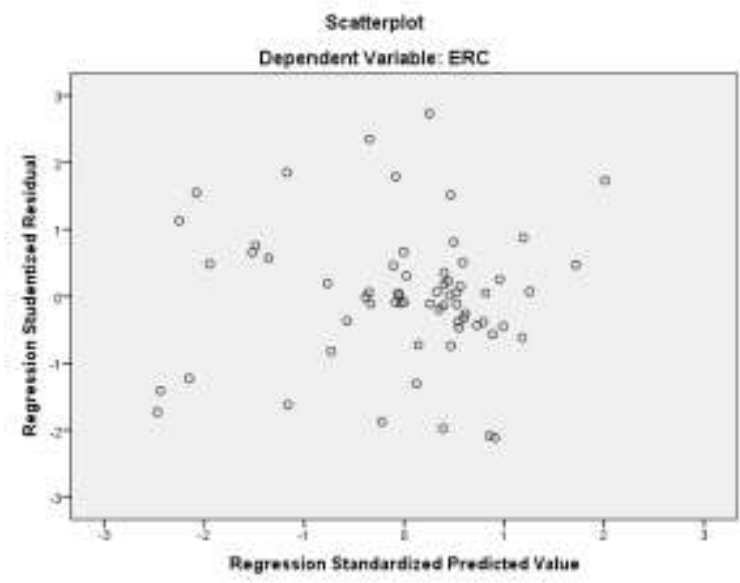

Heterokedastisitas test results with scatter plot diagram shows that the points spread randomly, do not form a particular pattern and spread over and below the number 0 on the y-axis. This means there is no heterokedastisitas on the regression model. So the regression capital is feasible to be used for ERC prediction based on independent variable input.

\section{Multiple Linear Regression Analysis:-}

Regression analysis aims to determine the effect of independent variables on the dependent variable. From the calculation using SPSS obtained as follows:

Table 4.11:- Results of Multiple Linear Regression

\begin{tabular}{|c|c|c|c|c|c|c|}
\hline \multirow{2}{*}{\multicolumn{2}{|c|}{ Model }} & \multicolumn{2}{|c|}{ Unstandardized Coefficients } & \multirow{2}{*}{$\begin{array}{c}\begin{array}{c}\text { Standardized } \\
\text { Coefficients }\end{array} \\
\text { Beta } \\
\end{array}$} & \multirow[t]{2}{*}{$\mathrm{t}$} & \multirow[t]{2}{*}{ Sig. } \\
\hline & & $\mathrm{B}$ & Std. Error & & & \\
\hline \multirow[t]{4}{*}{1} & (Constant) &, 095 & ,383 & & ,249 & ,804 \\
\hline & Size &,- 001 & ,013 &,- 008 &,- 067 & ,947 \\
\hline & Growth &, 176 & ,206 &, 106 &, 850 & ,399 \\
\hline & ROA &,- 447 & ,213 &,- 268 & $-2,103$ & ,040 \\
\hline
\end{tabular}

Based on the above table, it can be seen multiple linear regression analysis model is as follows:

$$
\mathrm{ERC}=0.095-0.001 \times 1+0.176 \mathrm{X} 2-0.447 \mathrm{X} 3+\varepsilon
$$

\section{The following explanation is as follows:-}

1. The value of $\beta 1=-0.001$, if firm size (X1) increases by one unit, the earnings response coefficient (Y) variable will decrease by 0.001 units with the assumption that other variables remain.

2. The value of $\beta 2=0.176$, if the growth of firm (X2) increases by one unit, then the earnings response coefficient (Y) variable will rise by 0.176 units with the assumption that other variables remain.

3. The value of $\beta 3=-0.447$, if the ROA (X3) increases by one unit, the earnings response coefficient (Y) variable will decrease by 0.447 units with the assumption that other variables remain 


\section{Hypothesis Testing: Partial Test (T-Test):-}

$\mathrm{T}$ - Test is used test persial independent variables significantly influence the dependent variable.

Based on the results of the above T test (table 4.11), the conclusion is:

1. Hypothesis $\left(\mathrm{H}_{1}\right)$; Influence of company size to ERC. The value of significance is $0.947>0.05$, This means the first hypothesis $\left(\mathrm{H}_{1}\right)$ is rejected, meaning firm size has no effect on ERC.

2. Hypothesis $\left(\mathrm{H}_{2}\right)$; The influence of corporate growth on ERC. Value significance of 0.399>0.05, This means the second hypothesis $\left(\mathrm{H}_{2}\right)$ is rejected, meaning that the company's growth does not affect the ERC variable.

3. Hypothesis $\left(\mathrm{H}_{3}\right)$; Effect of ROA on ERC. Value significance $0.040<0.05$ This means the third hypothesis $\left(\mathrm{H}_{3}\right)$ is accepted, meaning that ROA affect the ERC.

\section{Interpretation of Results:-}

Based on the results of the first hypothesis test $\left(\mathrm{H}_{1}\right)$ that company size does not affect earnings response coefficient significantly. The result of this research is in line with research of (Ngadiman, Hartini, \& Yurike, 2011) which found that firm size does not influence earnings response coefficient variable. However, the results of this study are not in line with the results of research (Kusuma, Indra, Nugroho, \& SetiyoJ., 2010) which obtained the result that the size of the company affect earnings response coefficient. That the size of the company is not a consideration for investors in making decisions, but investors are more concerned retun or risk obtained in the future.

Based on the results of the second hypothesis test $\left(\mathrm{H}_{2}\right)$ that the company's growth does not affect earnings response coefficient significantly. The results of this study are in line with the research (Sandi \& Umam K., 2013) However, the results of this study are not in line with the results of research (Naimah, Zahroh, Utama, \& Siddharta, 2006) which obtained the result that the growth of the company influence earnings response coefficient. Investors not only see the company grow well, but still think about the capital used in generating profits and see the stability of corporate growth that can be seen from the stability of the company's own sales growth.

Based on the results of the third hypothesis test $\left(_{\text {н3}}\right)$ that the profitability of the company affects earnings response coefficient significantly. The results of this study in line with research Pamungkas (2014) which obtained the result that the profitability of the company affect earnings response coefficient. However, the results of this study are not in line with the results of research (Anjelica, Keshia, Prasetyawan, \& Fani A, 2014) which resulted that the profitability of the company does not affect the variable earnings response coefficient. Profitability of a company that means as a company's ability in generating profits, become one of the elements in the decision of investors in investing, and has a negative direction because most investors first find out the profit information owned by the company before the date of publication of the financial statements themselves. So when the publication, the transaction has decreased because the transaction has been done before the publication.

\section{Conclusions and suggestions:-}

Based on the above discussion, it can be concluded several things as follows

1. The size of the company does not significantly affect the dependent variable ERC. The size of the company is not a consideration for investors in making decisions, but investors are more concerned retun or risks obtained in the future.

2. The growth of the company does not significantly affect the dependent variable ERC. Investors need a steady growth in the company for a longer period of time.

3. ROA significantly influence the dependent variable ERC. One factor in making a decision in investing is profit information.

\section{References:-}

1. Anjelica, Keshia, Prasetyawan, \& Fani A. (2014). Influence Profitability, Age Company, Company Size, Audit Quality and Capital Structure on the Quality of Earnings. Ultima Accounting, -.

2. Arfan, Antarsari, \& Ira. (2008). The effect of firm size, growth, and profitability on earnings response coefficients at manufacturing companies in Indonesia stock exchange. Telaah dan Riset Akuntansi, 50-64.

3. Collins, \& Kothari. (1989). An Analysis of Intertemporal and Cross-Sectional Determinants of Earnings Response Coeffients. Journal of Accounting dan Economics ed. 11, 143-181.

4. Diantimala, \& Yossi. (2008). The effect of conservative accounting, firm size, and default risk on earnings response coefficients. Telaah dan Riset Akuntansi, 102-122. 
5. Fama, \& Eugne F. (1970). Efficient Capital Market: A Review of Theory and Empirical Work. The Jurnal Of Finance, 383-417.

6. Ghozali, I. (2011). Multivariate Analytics Application with IBM SPSS Program 19. Semarang: Diponegoro University Publishing.

7. Kusuma, Indra, Nugroho, \& SetiyoJ. (2010). Influence of corporate social responsibility, firm size and profitability to earnings response coefficient. Accounting review, 127-148.

8. Murwaningsari, \& Etty. (2008). Some factors affect the earning response coefficient. National Symposium on Accounting 11.

9. Naimah, Zahroh, Utama, \& Siddharta. (2006). Influence of firm size, Growth, profitability to earnings response coefficient and coefficient Response of Equity Book Value: Study at manufacturing company in Indonesia Stock Exchange. National Symposium on Accounting, 23-26.

10. Ngadiman, Hartini, \& Yurike. (2011). The influence of firm size, persistence of accounting profit, capital structure, to earnings response coefficient on firms listed on Indonesia Stock Exchange. Accounting Krida Wacana 11(2).

11. Padan, \& Peni D. (2006). The influence of firm size, profit persistence, capital structure to earnings accounting response coefficient on firms listed on Indonesia stock exchange. National Symposium on Accounting IX (pp. 23-26). -: - .

12. Pamungkas, \& Bayu. (2014). The influence of the size of the public accountant firm, firm size, profitability, and leverage to earnings response coefficients (empirical studies in manufacturing companies listed on the Indonesian stock exchange). Doctoral Dissertation, Universty of Muhammadiyah Surakatar.

13. Paramita, Daniar, Hidayanti, \& Ery. (2013). Effect of earning response coefficient on stock prices (Studies on manufacturing companies listed on the stock exchange Indonesia). Journal of economic studies 3(1).

14. Pradipta, Hayu, \& Purwaningsih. (2015). The broad influence of corporate social responsibility and corporate disclosure on earning response coefficient, with firm size and leverage as control variables. Journal Ekonomi Akuntansi, 1-28.

15. Sandi, \& Umam K. (2013). Factors Affecting Earnings Response Coefficient. Accounting Analysis 2(3), -.

16. Sri, H. (2014). Effect of Profitability, Growth opportunity, Capital Structure to Company Value in Public Company in Indonesia. Bulletin of Monetary and Banking Economy ed. 16 - 2, 127-148. 